\title{
Top-down control in a tropical shallow lake of Northern Pantanal, Brazil
}

Controle descendente em um lago tropical raso do Pantanal Norte, Brasil

Roberto de Moraes Lima Silveira, Leide Laura Almeida Ribeiro de Paiva and

Janielly Carvalho Camargo

Departamento de Botânica e Ecologia, Instituto de Biociências, Universidade Federal de Mato Grosso - UFMT, Av. Fernando Correa da Costa, 2367, Boa Esperança, CEP 78060-900, Cuiabá, MT, Brazil e-mail: silveira@ufmt.br; leidelaura@gmail.com; janiellycamargo@hotmail.com

\begin{abstract}
Aim: To test the effect of fish exclusion over zooplankton and phytoplankton in a shallow lake in the floodplains of the Cuiabá River in Brazil's Pantanal; Methods: Fishes and two classes of zooplankton sizes were excluded using mesocosms $(100 \mu \mathrm{m}$ and $200 \mu \mathrm{m}$ mesh openings). The experiment lasted nine days with sampling at the beginning, six and nine days after the start of the experiment. Zooplankton and phytoplankton densities were compared among exclusion treatments and the open water which was considered as control areas by a Repeated Measures Analysis of Variance; Results: The zooplankton composition and densities differed considerably between the exclusion treatments and the control areas, with a predominance of Cladocera and Copepoda in the exclusion treatments and a predominance of Rotifera in the control areas. During the experiment, the composition of the phytoplankton assemblage showed no difference between the exclusion and the control. However, there was a marked reduction in the density of the Cyanophyta and Chlorophyta algae among the exclusion treatments; Conclusions: The increase in density and the variation in the zooplankton composition suggest that these organisms are controlled by the fish and demonstrate that the zooplankton may exert control over the density of phytoplankton.
\end{abstract}

Keywords: top-down control, zooplankton, shallow lake, Pantanal, trophic cascade.

Resumo: Objetivo: Testar o efeito da exclusão de peixes sobre o zooplâncton e o fitoplâncton em um lago da planície de inundação do Rio Cuiabá, Pantanal; Métodos: Peixes e duas categorias de tamanhos de zooplâncton foram excluídos utilizando tanques mesocosmos (com aberturas de malhas de $100 \mu \mathrm{m}$ e $200 \mu \mathrm{m}$ ). O experimento teve nove dias de duração, com amostragens realizadas no início e seis e nove dias após o início do experimento. As densidades do zooplâncton e fitoplâncton foram comparadas entre os tratamentos de exclusão e áreas abertas da lagoa, que foram consideradas áreas controle, por uma Análise de Variância com Medidas Repetidas; Resultados: A composição e a densidade do zooplâncton diferiram significativamente entre os tratamentos de exclusão e as áreas controle. Houve predominância de Cladoceras e Copépodes nos tratamentos de exclusão e predomínio de rotíferas nas áreas controle. Durante o experimento, a composição da assembléia fitoplanctônica não diferiu entre os tratamentos de exclusão e o controle. No entanto, houve uma redução significativa nas densidades de Cyanophyta e Chlorophyta nos tratamentos de exclusão quando comparadas às áreas controle; Conclusóes: $\mathrm{O}$ aumento na densidade e a variaçáo na composição do zooplâncton sugerem que os peixes exercem controle sobre o zooplâncton local tanto em sua quantidade como em sua composiçáo e que o zooplâncton também exerce controle sobre o fitoplâncton, porém apenas em seu aspecto quantitativo.

Palavras-chave: controle descendente, zooplâncton, lago raso, Pantanal, cascata trófica. 


\section{Introduction}

Aquatic freshwater systems have been exhaustively studied in terms of the type of control to which their communities are subjected. This control can be exerted by the quantity of nutrients and the primary production (bottom-up) or by predators (top-down). Identifying the type of control, as well as its relevance, has been the focus of extensive discussions to this day (Power, 1992; Vanni et al., 1997; Pace, 1999; Silveira and Moulton, 2000; Benndorf et al., 2002; FernándezAláez et al., 2004; Rejas et al., 2005). Most of the studies of these forces in lakes have involved temperate lakes, but little information is available about the subject for lakes in warmer climates or tropical regions (Hubble and Harper, 2000; Fernández-Aláez et al., 2004; Rejas et al., 2005).

Numerous studies of temperate lakes have revealed the existence of top-down forces, with emphasis on control by fish on the composition and abundance of zooplankton and phytoplankton (Gliwicz and Pijanowska, 1989; Vanni et al., 1997; Lazzaro et al., 2003; Fernández-Aláez et al., 2004). In tropical lakes, the few studies that deal with the subject consider bottom-up forces as the main determining mechanism of the community (Lazzaro, 1997; Pinel-Alloul et al., 1998). In fact, evidence of bottom-up control was found in 39 reservoirs in northeastern Brazil during the 1998 drought (Bouvy et al., 2000). However, recently revealed records of top-down control in reservoirs in northeastern Brazil are more correlated with fish trophic guilds than with their quantity of biomass (Lazzaro et al., 2003; Attayde and Menezes, 2008).

There is a paucity of data on the existence of topdown or bottom-up control in the Pantanal rivers and lakes. Shallow lakes are known to be suitable to develop trophic cascades (Benndorf et al., 2002). We hypothesize that tropical shallow lakes are subjected to trophic cascades or other sort of top-down effects. The main objectives of this study were therefore as follows: i) Determine whether the pelagic community of a lake in the Pantanal is subject to some type of control; ii) Evaluate the changes in the composition and density of the lake's components in the absence of fish; and iii) Evaluate whether the abundance and size of the lake's zooplankton influences the composition and density of its phytoplankton.

\section{Material and Methods}

\subsection{Study area}

The Santa Rosa lake ( $16^{\circ} 68^{\prime} 43^{\prime \prime} \mathrm{S}$ and $\left.56^{\circ} 46^{\prime} 33^{\prime \prime} \mathrm{W}\right)$, which covers an area of about 22.5 ha, is located on the Natural Heritage Private Reserve of the SESC Pantanal ecological ranch (RPPN-SESC Pantanal) (Figure 1). The Reserve lies in the northern portion of the Pantanal Mato Grosso floodplain, about $40 \mathrm{~km}$ south of the town of Poconé, in the state of Mato Grosso, Brazil. The Cuiabá River is part of the drainage basin of the Paraguay River, thus contributing to the Prata river basin. Its shape is characteristic of lakes that are formed from ancient meandering stretches which are frequent in the proximities of a main river. During the dry season, the average concentration of orthophosphate is $0.020 \mathrm{mg} . \mathrm{L}^{-1}$, ammonium is $0.025 \mathrm{mg} . \mathrm{L}^{-1}$, suspended phosphorus is $0.3 \mathrm{mg} . \mathrm{L}^{-1}$, suspended nitrogen is $0.2 \mathrm{mg} . \mathrm{L}^{-1}$, percentage of dissolved oxygen saturation during the day is approximately $50 \%$, electrical conductivity is approximately $60 \mu \mathrm{S} . \mathrm{cm}^{-1}$, and the $\mathrm{pH}$ is around 7.0 (Bleich et al., 2009).

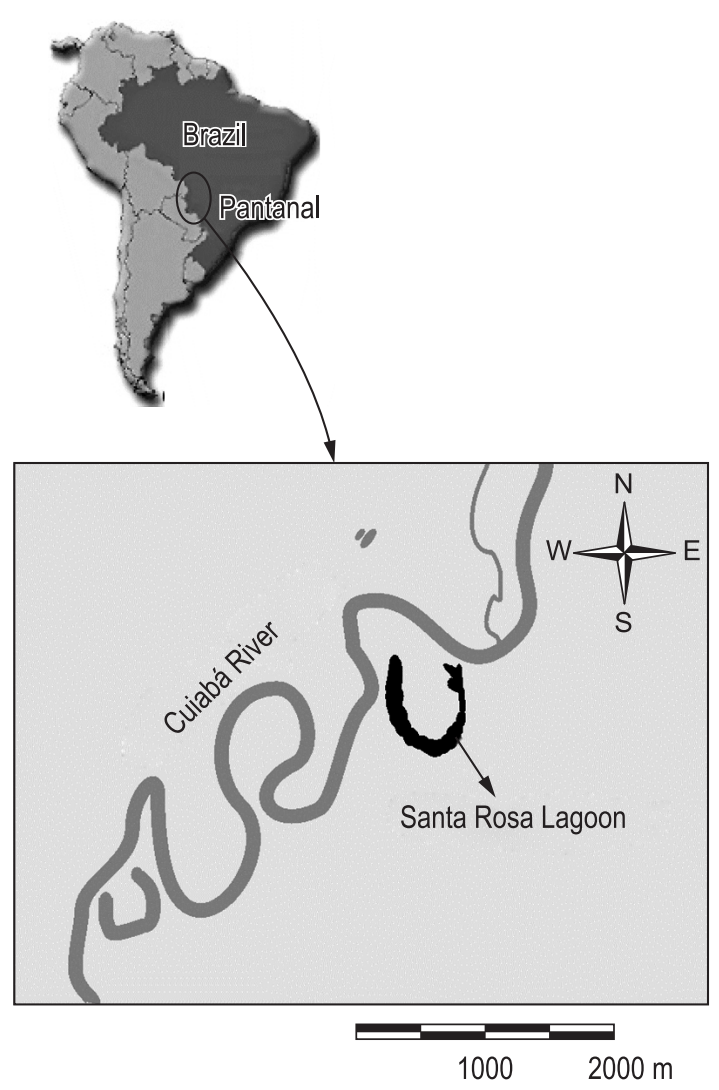

Figure 1. Pantanal of Mato Grosso location and Santa Rosa lagoon site $\left(16^{\circ} 68^{\prime} 43^{\prime \prime} \mathrm{S}\right.$ and $\left.56^{\circ} 46^{\prime} 33^{\prime \prime} \mathrm{W}\right)$ in the proximity of Cuiabá River. 


\subsection{Experimental design}

Conducted in October 2005, the experiment consisted of the exclusion of fishes and of two classes of zooplankton sizes, using three $200 \mu \mathrm{m}$ mesh mesocosms and three $100 \mu \mathrm{m}$ mesh mesocosms arranged in three groups in the central part of the lake. The use of mesocosms made of nylon netting was justified to allow free access to different classes of zooplankton sizes and free circulation of the lake's nutrients. Each group was composed of one mesocosm of each type and one sampling point in the lake itself, serving as a control area, separated from each other by about $5.0 \mathrm{~m}$ and from the other groups by approximately $20 \mathrm{~m}$. The mesocosms were $2 \mathrm{~m}$ high, with a $2 \mathrm{~m}$ diameter, the bottom composed of the netting in question and the top part open, but protected by a steel grate, which prevented flotsam and animals from entering without blocking the entrance of light. All the mesocosms were filled naturally by the lake water, which flowed through the netting when the devices were fixed to the clayey lake bottom. This procedure allowed only the organisms of the desired size classes to enter the treatment spaces. During the period of the experiment, the lake presented an average depth of $1 \mathrm{~m}$, so the mesocosms was filled with nearly $3000 \mathrm{~L}$ of water.

\subsection{Sampling and analysis of the samples}

Each mesocosms, as well as each control area, was sampled at the beginning and six and nine days after the start of the experiment. On each sampling day, we collected two samples per treatment unit to calculate the zooplankton density and two samples to calculate the density of phytoplanktonic algae. For each treatment and on each sampling day, we measured the electrical conductivity $\left(\mu S . \mathrm{cm}^{-1}\right)$, $\mathrm{pH}$ and dissolved oxygen (mg. $\left.\mathrm{L}^{-1}\right)$, using specific electrodes (WTW LF 340, Lutron DO-5510 and Lutron $\mathrm{pH}-206$, respectively), and the water temperature $\left({ }^{\circ} \mathrm{C}\right)$ using a thermistor coupled to a conductimeter.

To collect zooplankton and phytoplankton, we pumped $200 \mathrm{~L}$ of water twice for each treatment, and filtered the samples through $10 \mu \mathrm{m}$ mesh. The total of pumped water at each sampling day was equivalent of approximately $13 \%$ of the mesocosm volume. Zooplankton samples were stained immediately with Bengal Rose and fixed in $4 \%$ formaldehyde. Phytoplankton samples were fixed immediately in Transeau solution (Gross and Pfiester, 1988). We identified and quantified the organisms of the zooplankton under an optical microscope in a Sedgwick-Rafter cell. For each sample, we analyzed at least four $2 \mathrm{~mL}$ sub-sample, or until a total of 250 individuals had been counted (Pinto-Coelho, 2004). We also identified and quantified the phytoplanktonic algae, disregarding the ones that could be considered periphytic, analyzing five slides of deposited material in deposition chamber of $1.5 \mathrm{~mL}$ for each field sample or until we reached at least 100 cells of the most common type (Huszar and Giani, 2004).

\subsection{Statistical analysis}

To evaluate the effect of the exclusion of fishes and of some size classes on the composition of zooplankton and phytoplankton, we carried out Repeated Measures Analyses of Variance using the statistic software package SYSTAT ${ }^{\circledast} 11.0$.

\section{Results}

Although the parameters of the physical environment varied considerably between the sampling days, no difference was found between the treatments and the control.

\subsection{Composition and structure of the phytoplankton}

The composition of the phytoplankton assemblage remained approximately the same throughout the experiment, with most of the algae belonging to the phylum Cyanophyta (Figure 2).

Among the species of Cyanophyta, Microcystis sp. was the most abundant of all the species. The abundances of Chlorophyta and Bacillariophyta maintained similar proportions throughout the experiment and in all the treatments.

\subsection{Density of the phytoplankton}

The exclusion treatment with $200 \mu \mathrm{m}$ mesh showed a significant difference in the density of Cyanophyta and Chlorophyta algae when compared to the control. There was also a difference in these densities over time, but no significant interaction between the variable time and the density by mesh size. The exclusion treatment with $100 \mu \mathrm{m}$ mesh also generated significant differences in the density of these algae when compared with their density in the control (Figure 3a,b, Table 1). The density of Cyanophyta algae was greater than that of Chlorophyta algae by one order of magnitude, but both displayed a declining tendency within the exclusion treatments.

Only the taxa Microcystis sp. and Planktolyngbya sp. presented significantly differing densities between the exclusion treatments and 

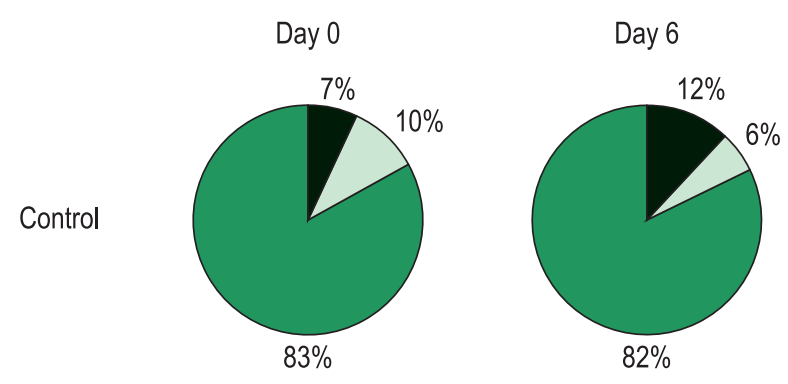

Day 9
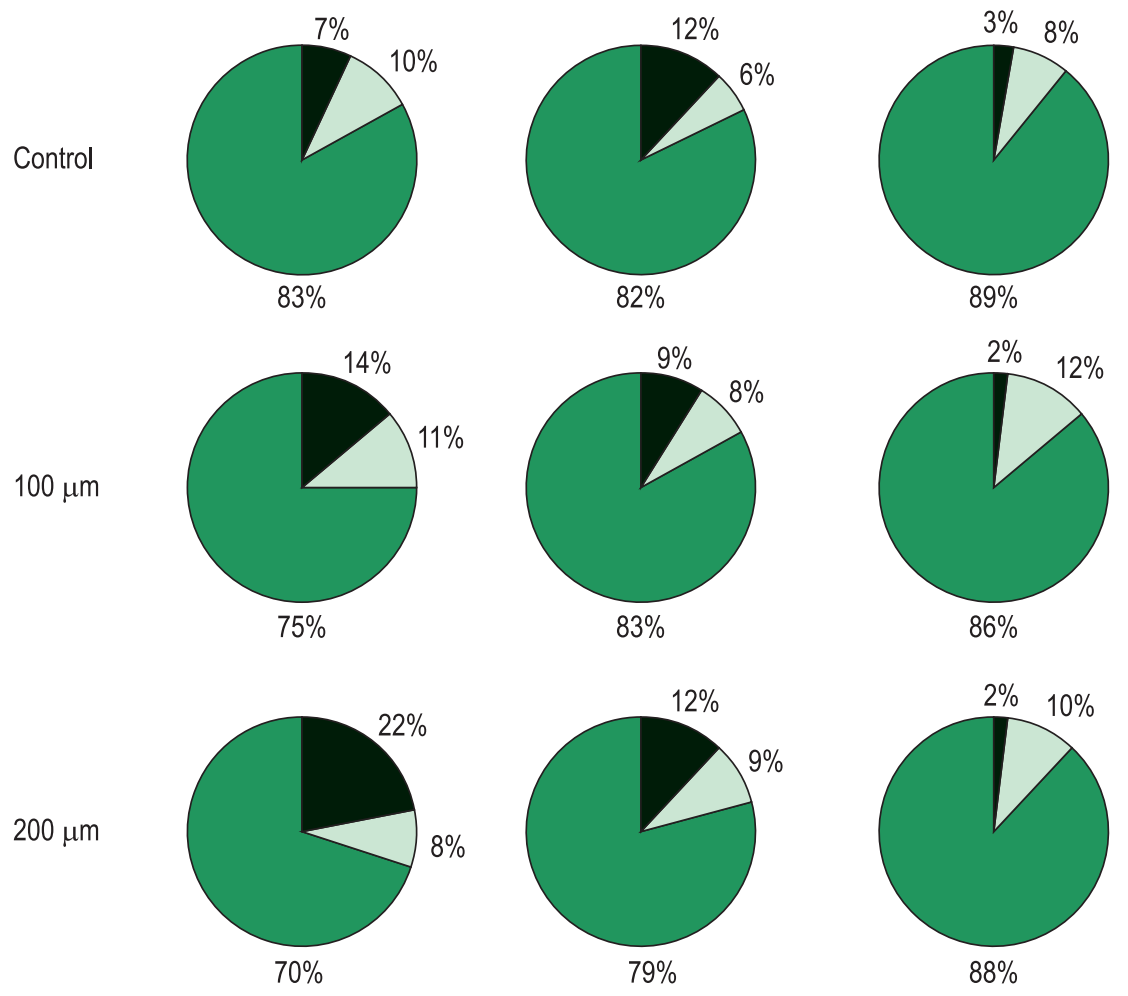

$\square$ Chlorophyta $\square$ Cyanophyta $\quad$ Bacillariophyta

Figure 2. Structure of phytoplankton assemblage during the experiment. Periphytic groups were not considered due to the mesocosms artificial effect over periphytic accumulation.
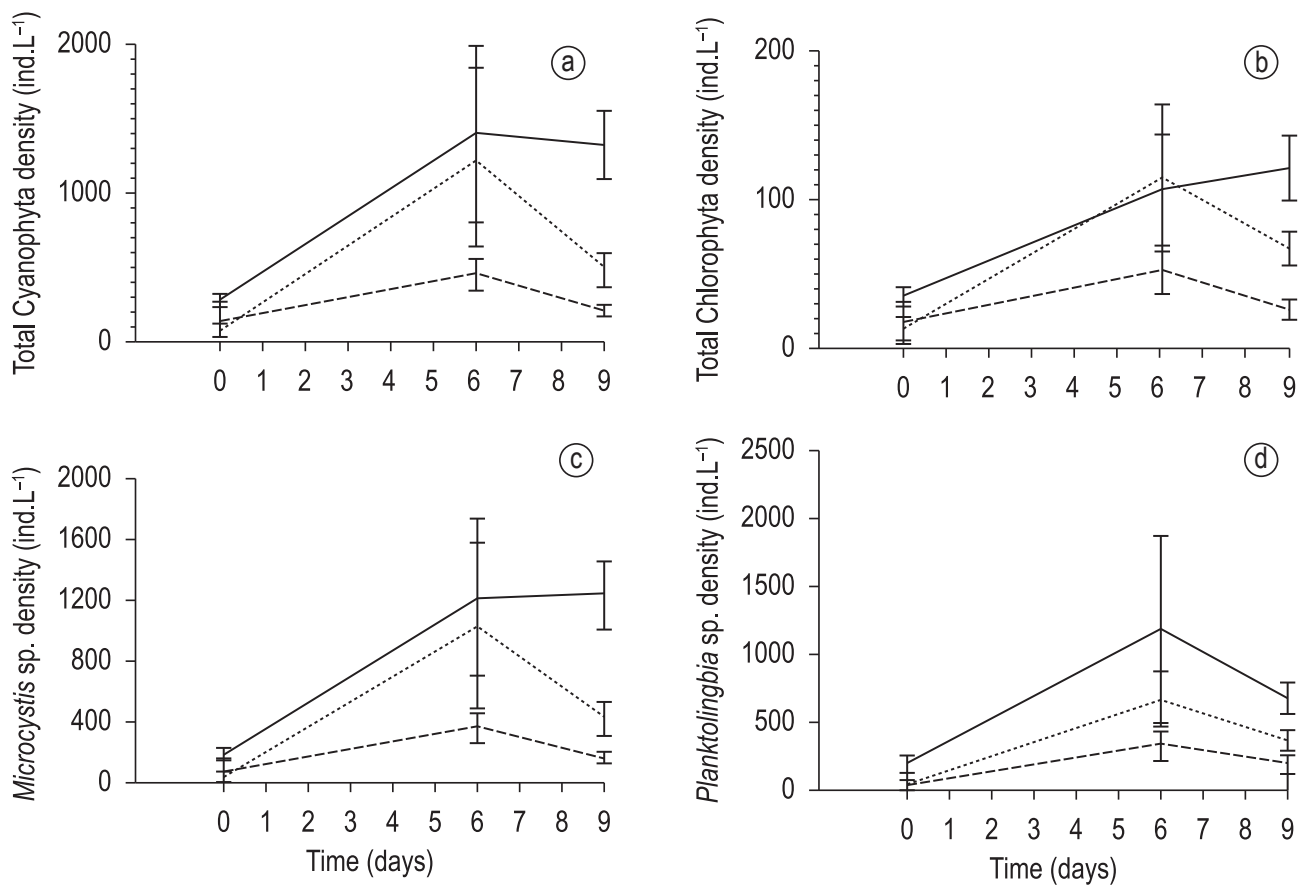

- Control $\quad \cdots \cdots-. .-100 \mu \mathrm{m}$----- $200 \mu \mathrm{m}$

Figure 3. Algae total density Cyanophyta (a) and Chlorophyta (b) and density of the main species of Cyanophyta: Microsystis sp. (c), Planktolingbia sp (d) for treatments during the experiment. 
Table 1. Results of univariate repeated measures ANOVA to test the effect of treatment, control and time on the density of phytoplankton organisms.

\begin{tabular}{|c|c|c|c|c|}
\hline \multirow[t]{2}{*}{ Variable } & \multirow[t]{2}{*}{ Source } & \multicolumn{2}{|c|}{ MS } & \multirow[t]{2}{*}{$\mathrm{F}$} \\
\hline & & Effect & Error & \\
\hline \multirow[t]{6}{*}{ Cyanophyta } & $100 \mu \mathrm{m}$ & 18.58 & 1.32 & $14.06^{* *}$ \\
\hline & Time $(100 \mu \mathrm{m})$ & 28.49 & 1.79 & $15.94^{\star \star \star}$ \\
\hline & $100 \mu \mathrm{m} \times$ Time & 6.58 & 1.79 & 3.68 \\
\hline & $200 \mu \mathrm{m}$ & 40.89 & 2.20 & $18.74^{* * \star}$ \\
\hline & Time $(200 \mu \mathrm{m})$ & 25.44 & 1.81 & $14.02^{\star * \star}$ \\
\hline & $200 \mu \mathrm{m} \times$ Time & 5.17 & 1.81 & 2.85 \\
\hline \multirow[t]{6}{*}{ Microcystis sp. } & $100 \mu \mathrm{m}$ & 18.91 & 1.21 & $15.64^{* *}$ \\
\hline & Time $(100 \mu \mathrm{m})$ & 30.65 & 1.62 & $18.92^{\star \star \star}$ \\
\hline & $100 \mu \mathrm{m} \times$ Time & 5.55 & 1.62 & 3.43 \\
\hline & $200 \mu \mathrm{m}$ & 40.35 & 1.84 & $21.92^{\star \star \star}$ \\
\hline & Time $(200 \mu \mathrm{m})$ & 27.19 & 1.67 & $16.24^{\star * \star}$ \\
\hline & $200 \mu \mathrm{m} \times$ Time & 4.25 & 1.67 & 2.54 \\
\hline \multirow[t]{6}{*}{ Planktolyngbya sp. } & $100 \mu \mathrm{m}$ & 14.88 & 0.84 & $17.62^{* *}$ \\
\hline & Time $(100 \mu \mathrm{m})$ & 29.12 & 1.63 & 17.86 \\
\hline & $100 \mu \mathrm{m} \times$ Time & 5.88 & 1.63 & 3.61 \\
\hline & $200 \mu \mathrm{m}$ & 35.12 & 1.72 & $20.42^{\star \star \star}$ \\
\hline & Time $(200 \mu \mathrm{m})$ & 26.57 & 1.49 & $17.81^{* * *}$ \\
\hline & $200 \mu \mathrm{m} \times$ Time & 4.75 & 1.49 & 3.18 \\
\hline \multirow[t]{6}{*}{ Chlorophyta } & $100 \mu \mathrm{m}$ & 6.49 & 0.53 & $12.21^{* *}$ \\
\hline & Time $(100 \mu \mathrm{m})$ & 15.84 & 0.94 & $16.74^{\star * \star}$ \\
\hline & $100 \mu \mathrm{m} \times$ Time & 2.99 & 0.94 & 3.17 \\
\hline & $200 \mu \mathrm{m}$ & 20.58 & 1.43 & $14.41^{* *}$ \\
\hline & Time $(200 \mu \mathrm{m})$ & 10.75 & 0.92 & $11.71^{* \star \star}$ \\
\hline & $200 \mu \mathrm{m} \times$ Time & 1.37 & 0.92 & 1.49 \\
\hline
\end{tabular}

${ }^{*} \mathrm{p}<0.05 ;{ }^{* *} \mathrm{p}<0.01 ;{ }^{* *} \mathrm{p}<0.001$. Degrees of freedom $=1$ (treatment) and 2 (time and treatment $\times$ time).

the control (Figure 3c,d, Table 1). The density of these taxa also varied significantly over time in both exclusion treatments (Table 1). In every case, there was an upward tendency followed by a decline in density in the exclusion treatments, with a consistently lower density of algae in the treatments with $200 \mu \mathrm{m}$ mesh (Figure 3c,d).

\subsection{Composition and structure of the zooplankton}

Throughout the experiment, the zooplankton assemblage in the control treatment consisted principally of animals of the Rotifera group. In the exclusion treatment with $100 \mu \mathrm{m}$ mesh, the proportion of Cladocera and Copepoda on start day of the experiment was very low compared to that of the control (Figure 4). This may have been due to the way in which the mesocosm was filled, filtering the water through the $100 \mu \mathrm{m}$ mesh as the device was immersed in the lake. At the end of the experiment, the proportion of these three main groups of zooplankton in this treatment was very different from that of the control, with Rotifera and Cladocera showing similar proportions (Figure 4).
In the exclusion treatment with $200 \mu \mathrm{m}$ mesh, the zooplankton composition underwent the greatest alterations during the experiment (Figure 4). The evolution of the composition of the assemblage during the experiment reveals a considerable alteration, with most of the zooplankton composed of Cladocera on the last two days of the experiment. This finding reinforces the tendency observed in the $100 \mu \mathrm{m}$ mesh exclusion treatment, but with an augmented decrease in Rotifera and increase in Copepoda and Cladocera in the exclusion treatment with $200 \mu \mathrm{m}$ mesh (Figure 4).

\subsection{Density of zooplankton}

The density of the Cladocera group increased significantly in the $200 \mu \mathrm{m}$ mesh exclusion treatment (Table 2). In the control, the density of this group remained unaltered during the experiment and although there was a variation in the $100 \mu \mathrm{m}$ treatment, it was not significant (Figure 5a, Table 2).

No significant difference was recorded in the density of the Rotifera group between the exclusion 

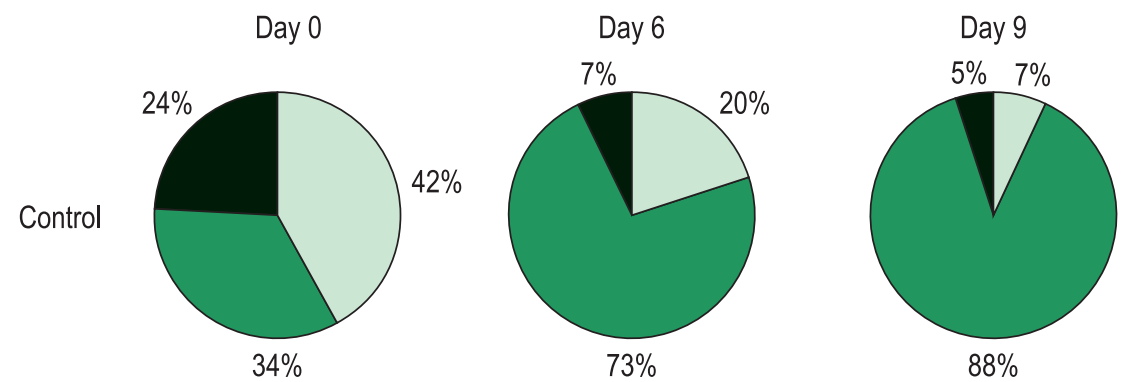

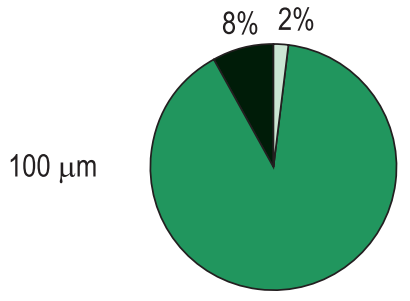

$90 \%$

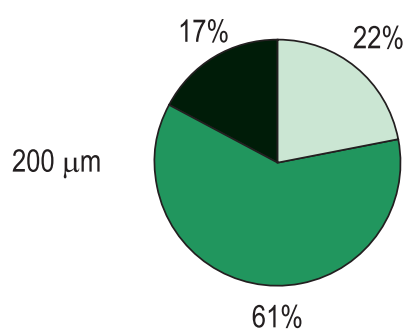

$61 \%$

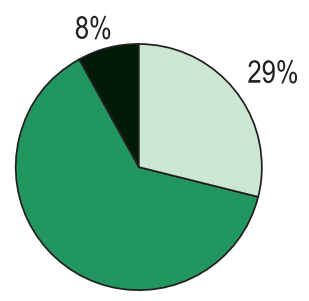

$63 \%$
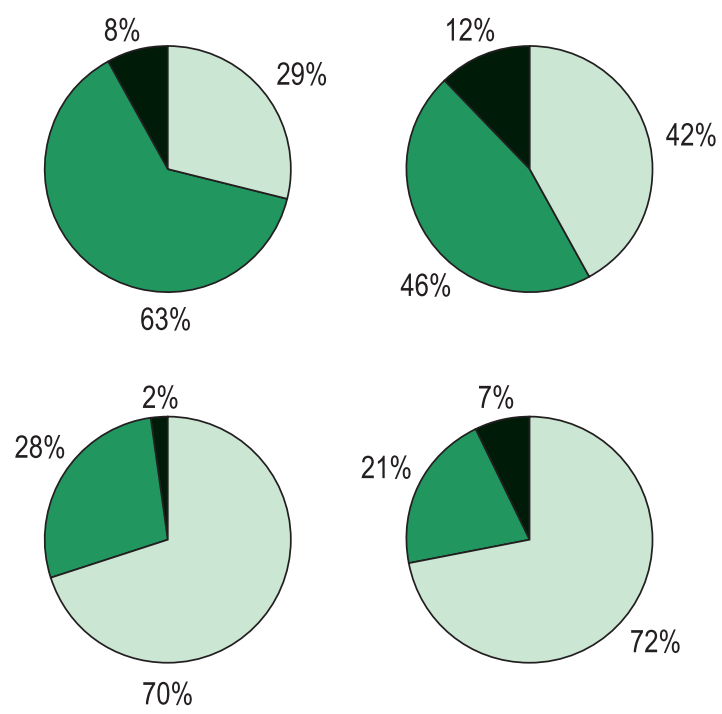

Cladocera $\square$ Rotirefa

Copepoda

Figure 4. Structure of zooplankton assemblage during the experiment.

treatments and the control (Figure 5b, Table 2). However, a significant difference in density was recorded in both treatments and in the control over time, with a significant interaction between time and the density of Rotifera in the $200 \mu \mathrm{m}$ mesh exclusion treatment (Figure 5b, Table 2). The Copepoda group showed no significant difference of density among the exclusion treatments (Figure 5c, Table 2). An analysis of the main categories of Copepoda indicates that the density of Cyclopoida varied over time in both exclusion treatments (Figure 5d, Table 2). Calanoida density also varied over time in both exclusion treatments, but not significantly (Figure 5e, Table 2).

\section{Discussion}

The use of mesocosms with different mesh dimensions allowed for the exclusion of organisms bigger than 100 and $200 \mu \mathrm{m}$, while simultaneously keeping the transfer of nutrients and the water conditions close to the lake's natural conditions, thus reducing the number of variables that could interfere in the results. The alterations occurring in the abiotic variables of the lake water during the experiment were observed both in the mesocosms and in the control, and showed values considered natural for this time of year (Bleich et al., 2009). Fish were excluded by the 100 and $200 \mu \mathrm{m}$ mesh. The $100 \mu \mathrm{m}$ mesh also provided exclusion by size of the zooplankton, without excluding any particular group. The $200 \mu \mathrm{m}$ mesh did not exclude zooplankton, since the taxa found during the experiment and in previous studies in the Santa Rosa Lake (Silveira, 2005, unpublished data) were small enough to pass through the mesh.

The exclusion by different mesh sizes showed similar responses. When there was no significant difference in the density of individuals between the exclusion treatment and the control, there was a significant difference between the exclusion time and the density of individuals, which is not uncommon when the effect of the treatment is time-dependent. This type of significant response also indicates that there was a difference between the 
Table 2. Results of univariate repeated measures ANOVA to test the effect of treatment, control and time on the density of zooplankton organisms.

\begin{tabular}{|c|c|c|c|c|}
\hline \multirow[t]{2}{*}{ Variable } & \multirow[t]{2}{*}{ Source } & \multicolumn{2}{|c|}{ MS } & \multirow[t]{2}{*}{$\mathrm{F}$} \\
\hline & & Effect & Error & \\
\hline \multirow[t]{6}{*}{ Cladocera } & $100 \mu \mathrm{m}$ & 0.00 & 0.49 & 0.00 \\
\hline & Time $(100 \mu \mathrm{m})$ & 35.60 & 1.05 & $33.92^{* * *}$ \\
\hline & $100 \mu \mathrm{m} \times$ Time & 16.45 & 1.05 & $15.69^{* * *}$ \\
\hline & $200 \mu \mathrm{m}$ & 22.91 & 0.41 & $55.54^{\star * *}$ \\
\hline & Time $(200 \mu \mathrm{m})$ & 22.03 & 0.91 & $24.27^{\star * *}$ \\
\hline & $200 \mu \mathrm{m} \times$ Time & 7.17 & 0.91 & $7.90^{* *}$ \\
\hline \multirow[t]{6}{*}{ Rotifera } & $100 \mu \mathrm{m}$ & 0.17 & 0.89 & 0.19 \\
\hline & Time $(100 \mu \mathrm{m})$ & 23.13 & 0.69 & $33.54^{\star * *}$ \\
\hline & $100 \mu \mathrm{m} \times$ Time & 1.06 & 0.69 & 1.54 \\
\hline & $200 \mu \mathrm{m}$ & 0.58 & 0.38 & 1.53 \\
\hline & Time $(200 \mu \mathrm{m})$ & 18.69 & 0.23 & $78.80^{\star * *}$ \\
\hline & $200 \mu \mathrm{m} \times$ Time & 2.27 & 0.23 & $9.60^{* *}$ \\
\hline \multirow[t]{6}{*}{ Copepoda total } & $100 \mu \mathrm{m}$ & 0.92 & 0.51 & 1.79 \\
\hline & Time $(100 \mu \mathrm{m})$ & 16.65 & 1.23 & $13.54^{* *}$ \\
\hline & $100 \mu \mathrm{m} \times$ Time & 3.42 & 1.23 & 2.78 \\
\hline & $200 \mu \mathrm{m}$ & 2.41 & 0.41 & $5.89^{*}$ \\
\hline & Time $(200 \mu \mathrm{m})$ & 6.72 & 0.70 & $9.61^{* * *}$ \\
\hline & $200 \mu \mathrm{m} \times$ Time & 0.52 & 0.70 & 0.75 \\
\hline \multirow[t]{6}{*}{ Cyclopoida } & $100 \mu \mathrm{m}$ & 1.76 & 0.64 & 2.73 \\
\hline & Time $(100 \mu \mathrm{m})$ & 7.72 & 1.13 & $6.85^{\star *}$ \\
\hline & $100 \mu \mathrm{m} \times$ Time & 0.93 & 1.13 & 0.82 \\
\hline & $200 \mu \mathrm{m}$ & 0.27 & 0.53 & 0.50 \\
\hline & Time $(200 \mu \mathrm{m})$ & 2.00 & 1.01 & 1.98 \\
\hline & $200 \mu \mathrm{m} \times$ Time & 1.69 & 1.01 & 1.67 \\
\hline \multirow[t]{6}{*}{ Calanoida } & $100 \mu \mathrm{m}$ & 1.01 & 0.89 & 1.13 \\
\hline & Time $(100 \mu \mathrm{m})$ & 29.22 & 1.60 & $18.23^{\star * *}$ \\
\hline & $100 \mu \mathrm{m} \times$ Time & 11.55 & 1.60 & $7.20^{* \star}$ \\
\hline & $200 \mu \mathrm{m}$ & 0.39 & 1.31 & 0.29 \\
\hline & Time $(200 \mu \mathrm{m})$ & 8.28 & 1.77 & $4.66^{*}$ \\
\hline & $200 \mu \mathrm{m} \times$ Time & 1.98 & 1.77 & 1.12 \\
\hline
\end{tabular}

${ }^{*} \mathrm{p}<0.05 ;{ }^{* *} \mathrm{p}<0.01 ;{ }^{* * *} \mathrm{p}<0.001$. Degrees of freedom $=1$ (treatment) and 2 (time and treatment $\times$ time).

exclusion and the control (Scheiner and Gurvitch, 2001). The exclusion treatment with $200 \mu \mathrm{m}$ mesh showed significant reductions in the densities of Cyanophyta and Chlorophyta, allied to a significant increase in the density of Cladocera. The exclusion treatment with $100 \mu \mathrm{m}$ mesh presented the same response, but of a lower intensity.

The results suggest the existence of a top-down effect of fish on the large size zooplankton elements, especially Cladocera, and a top-down effect of Cladocera on the phytoplankton. This type of interaction characterizes a trophic cascade (Paine, 1966; Power, 1984, 1990; Power et al., 1985; Kneib, 1988; Strong, 1992; Silveira and Moulton, 2000). Although the increasing of zooplankton and reducing of phytoplankton can lead to increasing in water transparency (Okun et al., 2008) we did not observe this because phytoplankton reduction was relative. At the end of the experiment, phytoplankton was not less abundant than it was at the beginning, but there was a marked difference among treatments.

In the Santa Rosa shallow lake, our results suggest that fish represented the main predator presence. The possible predation effect of fish on Cladocera was confirmed since the composition of zooplankton displayed a tendency to change from the predominance of Rotifera in the control to the predominance of Cladocera in the exclusion treatments. The predation of fishes on zooplankton can be classified as visual particulate, pump-action filtering and tow-net filtering (Lazzaro, 1987; Roche and Rocha, 2005). Visual particulate predation can be especially important in the structuring of the 

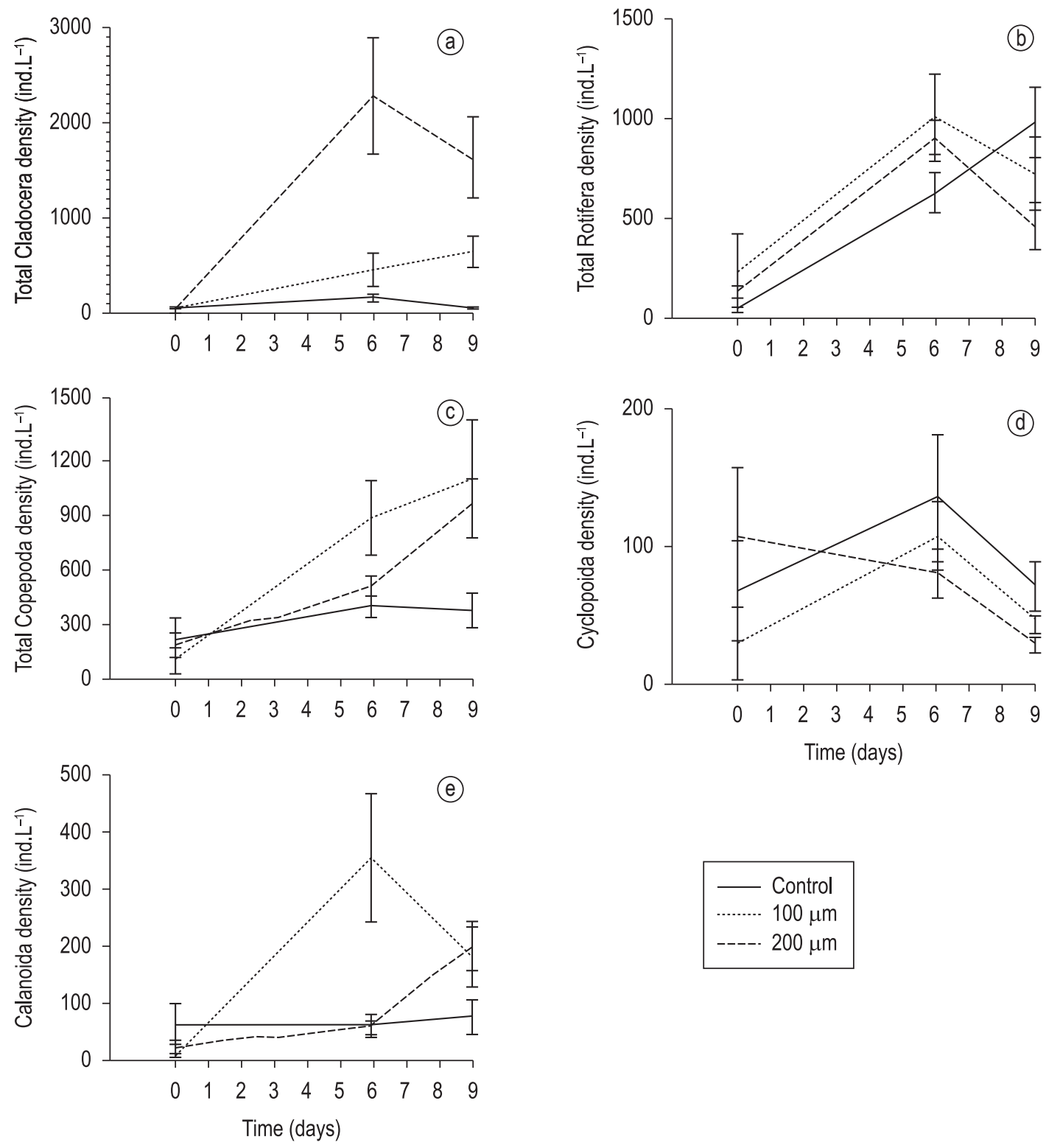

Figure 5. Zooplankton total density, Cladocera (a), Rotifera (b) and Copepoda (c) and the principal categories of Copepoda: Cyclopoida (d) and Calanoida (e) for treatments during the experiment.

zooplankton assemblage because it affects mainly large organisms (Tucker and Woolpy, 1984; Lazzaro, 1987; Gliwicz and Pijanowska, 1989; Arcifa et al., 1991; Nassal et al., 1998; Branstator and Holl, 2000).

Sommer et al. (2001) point out that the combined effect of Cladocera and Copepoda may reduce the phytoplankton biomass in situations in which the individual effect of either one or the other would not do so. In our experiment we were unable to determine whether the effect of zooplankton on phytoplankton was a combined action of Cladocera and Copepoda. However, the quantity of Cladocera was higher than that of Copepoda and most of the
Copepoda consisted of nauplii, whose ingestion rate is lower than that of adults. This reinforces the idea that the effect of zooplankton on phytoplankton is produced mainly by Cladocera.

The Rotifera group predominated in the composition of the community in the control and its density showed a tendency to increase naturally in the control during the period of the experiment. The exclusion treatments generated no marked variations in the density of most of the Rotifera.

Few studies have demonstrated the existence of top-down forces in tropical lakes (Hubble and Harper, 2000; Rejas et al., 2005). Most of 
the studies of these forces in lakes conducted in the tropics found a predominance of bottom-up forces (Pinel-Alloul et al., 1998; Bouvy et al., 2000). However, at least in Brazil, studies focusing on this issue have frequently been carried out in reservoirs, a fact that may have contributed strongly to the impression that tropical lakes are influenced principally by bottom-up forces (Bouvy et al., 2000). Fernando and Holcik (1991) argue that the effect of fish predation on zooplankton in the pelagic zone of reservoirs is minimal due to the difficulty fishes of lotic environments face in occupying this environment. Arcifa and Northcote (1997) reinforce this argument, pointing out that most of the fishes found in Brazilian reservoirs preferentially occupy the littoral zone with possible little influence over the pelagic community.

Studies in natural tropical lakes are rare and are even less common in natural floodplain lakes. In a study of Kenya's Naivasha Lake, Hubble and Harper (2000) found top-down control by zooplankton on phytoplankton, possibly dependent on the incidence of light and the quantity of nutrients. A noteworthy contribution by Rejas et al. (2005) shows a topdown effect of fish on Chaoborus larvae, indirectly favoring the remaining zooplankton community. However, chain interactions such as those found in our experiment, involving essentially fishes, Cladocera, Copepoda and phytoplankton, are common in lakes of temperate climates (FernándezAláez et al., 2004) but little known in the tropics.

Benndorf et al. (2002) criticize experiments of short duration in lakes. The authors comment on the improbability of lasting top-down effects on phytoplankton in deep mesotrophic or slightly eutrophic lakes. Nevertheless, Benndorf et al. (2002) admit that top-down effects on phytoplankton are expected in shallow lakes, as is the case of the Santa Rosa shallow lake.

The prevalence of top-down effects in lakes may vary greatly from one lake to another (Yoshida et al., 2003), as a function of its trophic state and the functional composition of its fish fauna (Benndorf et al., 2002; Lazzaro et al., 2003). Even so, our findings offer an important contribution toward understanding the principal forces existing in trophic chains of natural tropical lakes. Longer studies that can differentiate the individual effect of Cladocera and Copepoda on phytoplankton and the effect of the most abundant fish species on zooplankton are still necessary.

\section{Acknowledgements}

This study was funded by the PELD CNPq and FAPEMAT program and was conducted in partnership with the top management of the SESC-PANTANAL Reserve, MT, Brazil. We are deeply indebted to Dr. Flavia Nogueira, Dr. Lucia Mateus, Dr. Matthias Wantzen and Dr. Timothy P. Moulton for their support and encouragement. We also thank to Francisco "Chico Enésio", Alessandro Tortorelli, Ibraim Fantin-Cruz and Rosemary Lopes Silva for their valuable assistance on the field trips and laboratory analysis.

\section{References}

ARCIFA, MS. and NORTHCOTE, TG. 1997. Need for holistic approaches in food web experiments and biomanipulation in tropical lakes: a Brazilian reservoir experience. Verhandlungen des Internationalen Verein Limnologie, vol. 26, p. 661-665.

ARCIFA, MS., NORTHCOTE, TG. and FROEHLICH, O. 1991. Interactive ecology of two cohabiting characin fishes (Astyanax fasciatus and Astyanax bimaculatus) in a eutrophic Brazilian reservoir. Journal of Tropical Ecology, vol. 7, p. 257-268. http://dx.doi. org/10.1017/S0266467400005423

ATTAYDE, JL. and MENEZES, RF. 2008. Efects of fish biomass and planktivore type on plankton communities. Journal of Plankton Research, vol. 30, no. 8, p. 885-892. http://dx.doi.org/10.1093/plankt/ fbn051

BENNDORF, J., BÖING, W., KOOP, J. and NEUBAUER, I. 2002. Top-down control of phytoplankton: the role of time scale, lake depth and trophic state. Freshwater Biology, vol. 47, p. 2282-2295. http://dx.doi.org/10.1046/j.13652427.2002.00989.x

BLEICH, ME., SILVEIRA, RML. and NOGUEIRA, FMB. 2009. Limnological patterns in Northern Pantanal lagoons. Brazilian Archives of Biology and Technology, vol. 52, no. 3, p. 755-764. http://dx.doi. org/10.1590/S1516-89132009000300028

BOUVY, M., FALCÃO, D., MARINHO, M., PAGANO, M. and MOURA, A. 2000. Occurrence of Cylindrospermopsis (Cyanobacteria) in 39 Brazilian tropical reservoirs during the 1998 drought. Aquatic Microbial Ecology, vol. 23, p. 13-27. http:// dx.doi.org/10.3354/ame023013

BRANSTATOR, DK. and HOLL, CM. 2000. Planktivory by bluegill (Lepomis macrochirus) on Leptodora kinditi in a small North American lake. Hydrobiologia, no. 437, p. 101-106.

FERNÁNDEZ-ALÁEZ, M., FERNÁNDEZ-ALÁEZ, C., BÉCARE, E., VALENTIN, M., GOMA, J. and CASTRILLO, P. 2004. A 2-year experimental study 
on nutrient and predator influences on food web constituents in a shallow lake of north-west Spain. Freshwater Biology, vol. 49, p. 1574-1592. http:// dx.doi.org/10.1111/j.1365-2427.2004.01299.x

FERNANDO, CH. and HOLCIK, J. 1991. Fish in reservoirs. Internationale Revue der Gesamte Hydrobiologie, vol. 76, p. 149-167. http://dx.doi. org/10.1002/iroh.19910760202

GLIWICZ, MZ. and PIJANOWSKA, J. 1989. The role of predation in zooplankton succession. In SOMMER, U., ed. Plankton Ecology: Succession in Plankton Communities. New York: Springer-Verlag. p. 253-296.

GROSS, JL. and PFIESTER, LA. 1988. Blue-Green Algae of Lake Thunderbird Proc. Oklahoma Academy Science, vol. 68, p. 39-44.

HUBBLE, DS. and HARPER, DM. 2000. Top-down biological controls on tropical lakes productivity. Lakes \& Reservoirs: Research and Management, vol. 5, p. 187-194. http://dx.doi.org/10.1046/j.14401770.2000.00112.x

HUSZAR, VLM. and GIANI, A. 2004. Amostragem da comunidade fitoplanctônica em águas continentais: reconhecimento de padróes espaciais e temporais. In BICUDO, CEM. and BICUDO, DC., eds. Amostragem em Limnologia. São Carlos: RimaEditora. p. 133-147.

KNEIB, RT. 1988. Testing for indirect effects of predation in an intertidal soft-bottom community. Ecology, vol. 69, no. 6, p. 1795-1805. http://dx.doi. org/10.2307/1941158

LAZZARO, X. 1987. A review of planktivorous fishes: their evolution, feeding behaviour, selectivities and impacts. Hydrobiologia, vol. 146, p. 97-167. http:// dx.doi.org/10.1007/BF00008764

LAZZARO, X. 1997. Do the trophic cascade hypothesis and classical biomanipulation approaches apply to tropical lakes and reservoirs? Verhandlungen der Internationalen - Vereinigung für Theoretische und Angewandte Limnologie, vol. 26, p. 719-730.

LAZZARO, X., BOUVY, M., RIBEIRO-FILHO, RA., OLIVEIRA, VS., SALES, LT., VASCONCELOS, ARM. and MATA, MR. 2003. Do fish regulate phytoplankton in shallow eutrophic Northeast Brazilian reservoirs? Freshwater Biology, vol. 48, p. 649-668. http://dx.doi.org/10.1046/j.13652427.2003.01037.x

NASSAL, B., BURGHARD, W. and MAIER, G. 1998. Predation by juvenile roach on the calanoid copepod Eudiaptomus gracilis and the cyclopoid copepod Cyclops vicinus: a laboratory investigation with mixed and single prey. Aquatic Ecology, vol. 32, p. 335-340. http://dx.doi.org/10.1023/A:1009995432725

OKUN, N., BRASIL, J., ATTAYDE, JL. and COSTA, IAS. 2008. Omnivory does not prevent trophic cascade in pelagic food webs. Freshwater Biology, vol. 53, p. 129-138.

PACE, ML., COLE, JJ., CARPENTER, SR. and KITCHELL, JF. 1999. Trophic cascades revealed in diverse ecosystems. TREE, vol. 14, no. 12, p. 483-488. http://dx.doi.org/10.1016/S01695347(99)01723-1

PAINE, RT. 1966. Food web complexity and species diversity. American Naturalist, vol. 100, p. 850-860.

PINEL-ALLOUL, B., MAZUMDER, A., LAROIX, G. and LAZZARO, X. 1998. Les réseaux trophiques lacustres: structure, fonctionnement, interactions et variations spatio-temporelles. Revue des Sciences de l'Eau, no. spécial 10 ème anniversaire, 163-197.

PINTO-COELHO, RM. 2004. Métodos de coleta, preservação, contagem e determinação de biomassa em zooplâncton de águas epicontinentais. In BICUDO, CEM. and BICUDO, DC., eds. Amostragemem Limnologia. Sáo Carlos: RimaEditora. p. 149-166.

POWER, ME. 1984. Depth distribution of armored catfish: predator-induced resource avoidance? Ecology, vol. 65, p. 523-528.

POWER, ME. 1992. Top-down and bottom-up forces in food webs: do plants have primacy. Ecology, vol. 73, no. 3, p. 733-746.

POWER, ME., MATTHEWS, WJ. and STEWART, AJ. 1985. Grazing minnows piscivorous bass, and stream algae: dynamics of a strong interaction. Ecology, vol. 65, p. 1448-1456.

REJAS, D., DECLERCK, S., AUWERKERKEN, J., TAK, P. and DE MEESTER, L. 2005. Plankton dynamics in a tropical floodplain lake: fish, nutrients, and the relative importance of bottom-up and top-down control. Freshwater Biology, vol. 50, p. 52-69. http://dx.doi.org/10.1111/j.13652427.2004.01306.x

ROCHE, KF. and ROCHA, O. 2005. Ecologia trófica de peixes com ênfase na planctivoria em ambientes lênticos de água doce do Brasil. São Carlos: RimaEditora. 136 p.

SCHEINER, SM. and GUREVITCH, J. 2001. Design and Analysis of Ecological Experiments. Oxford: University Press ed. New York.

SILVEIRA, RML. and MOULTON, TP. 2000. Modelling the food web of a stream in Atlantic forest. Acta Limnologica Brasiliensia, vol. 12, no. 1, p. 63-71.

SOMMER, U., SOMMER, F., SANTER, B., JAMIESON, C., BOERSMA, M., BECKER, C. and HANSEN, T. 2001. Complementary impact of copepods and cladocerans on phytoplankton. Ecology Letters, vol. 4, p. 545-550. http://dx.doi. org/10.1046/j.1461-0248.2001.00263.x

STRONG, DR. 1992. Are trophic cascades all wet? Differentiations and donor-control in speciose ecosystems. Ecology, vol. 73, no. 3, p. 747-757. http:// dx.doi.org/10.2307/1940154 
TUCKER, RP. and WOOLPY, SP. 1984. The effect of parthenogenic eggs in Daphnia magna on prey location by the bluegill sunfish (Lepomis macrochirus). Hydrobiologia, vol. 109, p. 215-217. http://dx.doi. org/10.1007/BF00007738

VANNI, MJ., LAYNE, CD. and ARNOTT, SE. 1997. "Top-down" trophic interactions in lakes: effects of fish on nutrient dynamics. Ecology, vol. 78, no. 1, p. 1-20.
YOSHIDA, T., URABE, J. and ELSER, J. 2003. Assesment of "top-down" and "bottom-up" forces as determinants of rotifer distribution among lakes in Ontario, Canada. Ecological Research, vol. 18, p. 639-650. http://dx.doi.org/10.1111/j.14401703.2003.00596.x

Received: 02 September 2010 Accepted: 15 June 2011 